\title{
Determination of Some Physicochemical and Microbiological Characteristics of Sewage Samples from Domestic, House-boat and Off-shore Facilities Discharge Point.
}

\author{
${ }^{1}$ JOEL, O. F.; ${ }^{2}$ AKINDE, B. S.; ${ }^{3}$ NWOKOYE, C. U. \\ ${ }^{1}$ Department of Petroleum and Gas Engineering, Faculty of Engineering, University of Port Harcourt, Nigeria. \\ 234-8037099211/08052276568; E-mail:Ogbonna.joel@yahoo.com \\ ${ }^{2}$ Department of Applied and Environmental Biology, Rivers State University of Port Harcourt, Nigeria. \\ ${ }^{3}$ Pollution Control and Environmental Management Limited, Port Harcourt, Nigeria.
}

\begin{abstract}
Test was conducted to determine some physico- chemical and microbiological parameters from samples of sewage effluent collected from domestic, house-boat, and offshore facilities respectively at the discharge point to the recipient environment. Among the parameters determined included: Total chlorine, Biological Oxygen demand (BOD), Total Suspended Solids (TSS), Dissolved Oxygen (DO) and faecal coliform. Test results indicated that the total chlorine had values which ranged from $(<0.01-0.10) \mathrm{mg} / 1$ for the domestic facilities, the house-boat facilities values ranged from $(0.01-0.12) \mathrm{mg} / 1$. The values for the offshore facilities ranged from $(<0.01-4.0 \mathrm{mg} / 1)$. The $\mathrm{BOD}_{5}$ values for the domestic facilities ranged from $(<0.01-240) \mathrm{mg} / \mathrm{l}$, the house -boat facilities ranged from $(45.60-$ $80.00) \mathrm{mg} / \mathrm{l}$. The value of the offshore facilities was $20 \mathrm{mg} / 1$ for all the three points tested. The result of the TSS indicated that for the domestic facilities, the values ranged from (75.0-115) $\mathrm{mg} / \mathrm{l}$, the house-boat facilities values ranged from (66-182) $\mathrm{mg} / \mathrm{l}$. and for the offshore facilities, results ranged from (60-265) $\mathrm{mg} / \mathrm{l}$. The DO results from the domestic facilities indicated a range of $(0.18-5.92) \mathrm{mg} / \mathrm{l}$. The result from the house -boats ranged from (2.02.90) $\mathrm{mg} / \mathrm{l}$, the offshore facilities results ranged from $(3.21-5.32) \mathrm{mg} / \mathrm{l}$. The faecal coliform for the domestic facilities had a value which ranged from (14-1600) cfu/100ml. the house-boat facilities values ranged from (180-290) $\mathrm{cfu} / 100 \mathrm{ml}$. The offshore facilities had values which ranged from (14-1600) cfu/100ml. Most of these results were higher than limits specified by the regulatory level (DPR) and an indication that the recipient environment was polluted and poses a great concern. In a place like Nigeria, where there are no sewerage treatment systems, it is indiscriminately disposed into rivers without treatment and such rivers serve as sources of drinking water. This water pollution is of great concern and has resulted to diseases such as typhoid and cholera. Therefore, proper treatment of sewage before discharging into the recipient environment is imperative. @ JASEM
\end{abstract}

Growing volumes of industrial and municipal sewage are being discharged at surface waters. Treatment provided is frequently inadequate to protect the desired uses of the receiving waters. Limited institutional capacity and financial resources make for difficult choices as governments try to optimize their investments in municipal systems and establish practical requirements for industrial / municipal sewage treatment.

In many urban situations, both the municipal sewage system and industrial wastewater treatment are inadequate. A municipal sewage network may be in place, but coverage is usually incomplete, and the level of treatment provided is inadequate. Even where reasonable treatment facilities exist, poor maintenance and operation often result in failure to meet design effluent levels. In such circumstances, management of industrial wastewater discharge is also frequently poor, with uncontrolled discharges of untreated effluent to surface water or to the sewer system. The result is high levels of water pollution. It is not uncommon for steams or water bodies to be almost or completely anaerobic and heavily polluted with organic compounds, pathogens, and heavy metals (World Bank, 1993). As organic wastes get into water, bacteria reproduce rapidly and use the entire supply of oxygen, leading to the death of fish and other living organisms. Excessive nutrients such as nitrogen and phosphorus, aquatic plants and algae proliferation trigger eutrophication, especially in closed water bodies. Numerous investigations were made to characterize domestic sewage and determine the occurrence and survival of enteric pathogens and coliform bacteria in seawater (Olayemi and Opaleye, 1990).

Many public health agencies have however, established water quality indicator standards for marine waters under their jurisdiction. For sewage of production facilities toilets continuously manned by 10 or more persons, Department of Petroleum Resources (DPR) requires biological treatment, preferably by a standard sewage Wastewater Treatment Plant (WWTP). This will be followed by mandatory monitoring of dissolved oxygen (DO), biological oxygen demand $\left(\mathrm{BOD}_{5}\right)$, total suspended solids (TSS), residual chlorine and faecal coliform in treated sewage before discharge into the sea (DPR, 2002).

The objective of this research is to determine the physicochemical characteristics of sewage effluent from three sewage points and compare their results for the purpose of improvement 


\section{MATERIALS AND METHODS \\ Sample collection}

Sewage effluent samples were aseptically collected from domestic, house-boat and offshore discharge points for physico-chemical and coliform characterization using 1 litre plastic and $200 \mathrm{ml}$ sterile glass bottles respectively. Samples were stored in ice packs $\left(4 \pm 2^{\circ} \mathrm{C}\right)$ and transferred to the laboratory for analysis.

Dissolved Oxygen These were determined electrometrically with a multi- parameter data logger (Hanna model HI991300).

\section{Total Suspended Solids}

Total suspended solid (TSS) was determined with a membrane filter apparatus in accordance with APHA $2540 \mathrm{D}$. About $100 \mathrm{ml}$ of the water sample was filtered through dried pre- weighed $0.45 \mu \mathrm{m}$ filter paper and oven dried at $105 \pm 5^{\circ} \mathrm{C}$ for one hour. After which the paper was cooled in a desiccator and weighed. In order to obtain a realistic data devoid of salt interference from seawater, the filter apparatus after filtration of the seawater was thoroughly washed with distilled water. The determined residue was used to calculate the TSS.

\section{Biological Oxygen Demand}

This was determined using APHA5210B method. The $\mathrm{BOD}_{5}$ test measures the depletion of dissolved oxygen by the activity of microorganisms as they oxidize the organic matter in a given sample. The samples were diluted appropriately seeded and incubated in the dark for 5 days at $20^{\circ} \mathrm{C}$. The residual dissolved oxygen was determined after incubation period and the $\mathrm{BOD}_{5}$, calculated afterwards.

\section{Residual Chlorine}

The residual $\mathrm{Cl}_{2}$ was estimated using the $\mathrm{HACH}$ test kit from which $25 \mathrm{ml}$ of the waste water sample was measured into a pre-calibrated cell bottle and onecontent of one powder pillow was added to the cell bottle and swirled. The waste water sample was poured into the cell bottle to the graduated mark. Another sample was poured in without the powder pillow into another cell bottle as blank. Both cell bottles were put into the test kit with a graduated color comparator and were allowed to stand between 3-6 mins for residual chlorine before the $\mathrm{mg} / \mathrm{l}$ concentration was read.

\section{Faecal Coliform Bacteria Count}

About $100 \mathrm{ml}$ of the water samples was filtered through membrane filter with the aid of vacuum pump. The filter membrane was placed in A MacConkey agar plate. This was then incubated using an incubator pre-set to $44.5 \pm 2{ }^{\circ} \mathrm{C}$ for $24 \mathrm{hrs}$. Observation was made for colony development on the filter membrane. The colonies were then counted as colony forming unit per $100 \mathrm{ml}$.

\section{RESULTS AND DISCUSSION}

Table 1: Number of Samples from Different Facilities

\begin{tabular}{lll}
\hline S/N & SAMPLE TYPES & NUMBER OF SAMPLES \\
\hline 1. & Domestic sample & $(3)$ \\
2. & House-boat sample & $(3)$ \\
3. & Offshore sample & $(3)$ \\
\hline
\end{tabular}

Table 2: Sewage effluent result of the Domestic Facility

\begin{tabular}{|c|c|c|c|c|c|}
\hline Parameter & Total Chlorine (mg/l) & $\begin{array}{l}\mathrm{BOD}_{5} \\
(\mathrm{mg} / \mathrm{l})\end{array}$ & $\begin{array}{c}\text { TSS } \\
(\mathrm{mg} / \mathrm{l})\end{array}$ & $\begin{array}{c}\mathrm{DO} \\
(\mathrm{mg} / \mathrm{l})\end{array}$ & $\begin{array}{l}\text { Faecal Coliform } \\
\text { (cfu/100ml) }\end{array}$ \\
\hline \multicolumn{6}{|l|}{ Domestic Locations } \\
\hline Facility 1 & $<0.01$ & 240 & 115 & 0.18 & 350 \\
\hline Facility 2 & 0.10 & 120 & 75.0 & 5.22 & 14 \\
\hline Facility 3 & 0.10 & $<0.01$ & 80.0 & 5.92 & 1,600 \\
\hline DPR Limits & 0.8 & 30 & 45 & $4.0-5.0$ & 200 \\
\hline
\end{tabular}

\footnotetext{
* Corresponding author: Joel, O. F.
} 
Table 3: Sewage effluent result of the House-boat Facility

\begin{tabular}{lccccc}
\hline Parameter & Total Chlorine $(\mathrm{mg} / \mathrm{l})$ & $\begin{array}{l}\mathrm{BOD}_{5} \\
(\mathrm{mg} / \mathrm{l})\end{array}$ & $\begin{array}{c}\mathrm{TSS} \\
(\mathrm{mg} / \mathrm{l})\end{array}$ & $\begin{array}{c}\mathrm{DO} \\
(\mathrm{mg} / \mathrm{l})\end{array}$ & Faecal Coliform (cfu/100ml) \\
\hline House Boat Locations & & & & & 180.0 \\
\hline 1 & 0.08 & 45.60 & 66.0 & 2.90 & 290.0 \\
2 & 0.01 & 80.00 & 170.0 & 2.00 & 230.0 \\
\hline DPR Limits & 0.04 & 73.10 & 182.0 & 2.50 & 200 \\
\hline
\end{tabular}

Table 4: Sewage effluent result of the Offshore Facility

\begin{tabular}{lccccc}
\hline Parameter & $\begin{array}{l}\text { Total Chlorine } \\
(\mathrm{mg} / \mathrm{l})\end{array}$ & $\begin{array}{l}\mathrm{BOD}_{5} \\
(\mathrm{mg} / \mathrm{l})\end{array}$ & $\begin{array}{c}\mathrm{TSS} \\
(\mathrm{mg} / \mathrm{l})\end{array}$ & $\begin{array}{c}\text { DO } \\
(\mathrm{mg} / \mathrm{l})\end{array}$ & $\begin{array}{l}\text { Faecal Coliform } \\
(\mathrm{cfu} / 100 \mathrm{ml})\end{array}$ \\
Location & & & & & \\
\hline Offshore Locations & $<0.01$ & 20.0 & 265 & 3.21 & 1,600 \\
Rig 1 & 4.00 & 20.0 & 60.0 & 5.32 & 14 \\
Rig 2 & $<0.01$ & 20.0 & 85.0 & 3.86 & 350 \\
Rig 3 & 1.5 & 45 & - & $4.0-5.0$ & 400 \\
\hline DPR Limits & 1.5 & & \\
\hline
\end{tabular}

Test was conducted to determine some physicochemical and microbiological parameters from samples of sewage effluent collected from domestic, house-boat, and offshore facilities respectively at the discharge point to the recipient environment.

Table 1 presents results from the domestic sewage collected from three points. Among the parameters determined included: Total chlorine, Biological Oxygen demand (BOD), Total Suspended Solids (TSS), Dissolved Oxygen (DO) and Faecal coliform. Test results indicated that the total chlorine had values which ranged from $(<0.01-0.10) \mathrm{mg} / \mathrm{l}$ for the domestic facilities respectively, this was below the regulatory specified limits of $(0.8 \mathrm{mg} / \mathrm{l})$. However, the faecal coliforms for the domestic facilities had a value which ranged from (14-1600) $\mathrm{cfu} / 100 \mathrm{ml}$. Two of the facilities had values above specified regulatory limits of $200 \mathrm{cfu} / 100 \mathrm{ml}$. Since the residual chlorine content will help destroy the pathogens, it might be necessary to increase the chlorine dosage in the sewage treatment system to reduce the microbial load. The $\mathrm{BOD}_{5}$ results ranged from $(0.01-240) \mathrm{mg} / \mathrm{l}$, two of the facilities had higher values above that specified by regulatory agents $(30 \mathrm{mg} / \mathrm{l})$. The relatively higher values of $\mathrm{BOD}_{5}$ indicate pollution of the water body by biodegradable matter. $\mathrm{BOD}_{5}$ measurement serves a useful function in determining the strength of a waste stream in terms of excess degradable organic matter that may be present beyond established background levels (World Bank,
1993). The total suspended solids (TSS) in the domestic sample ranged from (75-115) $\mathrm{mg} / \mathrm{l}$. All the three points tested indicated higher values than specified $(45 \mathrm{mg} / \mathrm{l})$ by regulatory agents. There might be utmost need to undertake centrifugation exercise in order to separate the suspended solids before discharge into the water body. The DO results from the domestic facilities ranged from $(0.18-5.92) \mathrm{mg} / \mathrm{l}$ with one of the points having a value lower than specified (4.0- 5.0) $\mathrm{mg} / \mathrm{l}$.

Table 2 shows results from house-boat facilities. The Total chlorine value ranged from $(0.01-0.08) \mathrm{mg} / \mathrm{l}$. This was within specified limit and does not pose a concern. However, the faecal coliforms results ranged from (180-290) cfu/100ml, indicating values above specified limits in all the points. This shows that the chlorine treatment was not effective in destroying the microbes and needed an increase in the chlorine loading. The $\mathrm{BOD}_{5}$ values ranged from (45.0-80.0) $\mathrm{mg} / \mathrm{l}$, all the values were above specified limits. This is an indication of water pollution. The TSS results ranged from (66-182) $\mathrm{mg} / \mathrm{l}$, indicating values above specified limits in all the three discharge points tested. Prudent measures should be undertaken to separate the suspended solids before discharge. The DO results were all below the minimum value expected for effluent discharge. This is a great concern and will pose danger for aquatic organisms.

\footnotetext{
${ }^{*}$ Corresponding author: Joel, O. F.
} 
Table 3 presents results from the offshore facilities. The total chlorine level ranged from $(0.01-4.0) \mathrm{mg} / \mathrm{l}$. The faecal coliforms values ranged from (14-1600) $\mathrm{cfu} / 100 \mathrm{ml}$. The point that had the lowest faecal coliforms of $14 \mathrm{cfu} / 100 \mathrm{ml}$ showed that the total chlorine level was far higher than the specified $(4 \mathrm{mg} / \mathrm{l}$ as against $1.5 \mathrm{mg} / \mathrm{l})$. Though the faecal coliform was below specified limit, the high total residual chlorine is of big concern and a threat for aquatic organisms. Though there are no effluent discharge limits for TSS and $\mathrm{BOD}_{5}$ values were below limits, prudent measures should be taken to ensure the effluent are properly treated before discharge.

In Nigeria, since there are no sewerage, one would have to start by trucking or hauling the sewage to the treatment facility. A reservoir could be built to hold enough volume to constantly supply the treatment plant on a batch treatment methodology. The wastewater treatment plant should be designed to purify city waste water so that it can be returned to the river to be reused. For new towns, Government should plan to install a wastewater treatment system from the beginning. Home builders should be required to connect all homes built to a sewer line that is connected back to the sewage treatment plant. Homes in the western world are expensive partly because all homes are required to be connected to a sewer line. These lines are buried deep underground such that it is difficult to accidentally break them when constructing other structure. One method of disposal that can be very beneficial in a place like Nigeria would be land application as soil conditioner and/or fertilizer depending on the nitrogen content of the sludge. The treated sludge could generate a revenue stream from sale to resident farmers as soil conditioner or fertilizer.

Conclusion: Effective sewage management will help to meet up with the long-term challenges of sound environmental management, improve standard of living and health, enhance economic opportunities and make for sustainable development. To make this a win-win venture and sustainable, the Government should provide the legislation, initial equity and driving force, home owners to pay for the services provided, technocrats to provide the technology and private enterprises to provide the Services.

\section{REFERENCES}

APHA, (1985). Standard Methods for the examination of Water and Wastewater. American Public Health Association, 15 Ed, Pg 128.

ASTM, (1995). Ed. Water and Environmental Technology, American Standard Testing Method, 1995 Vols. $1 \& 2$.

DPR, (2002). Environmental Guidelines and Standards for the Petroleum Industry in Nigeria (EGASPIN), Revised Edition 2002.

FEPA, (1991). Federal Republic of Nigeria: (S.I8), Nation Environmental Protection (Effluent Limitation) Regulations 1991. S.I.9 Nation Environmental protection (pollution Abatement in Industries and Facilities Generating Wastes.). Regulations 1991. Federal Republic of Nig. Official Gazette No. 42, Vol 78, $20^{\text {th }}$ August, 1991. Pg. 38.

Olayemi, AB and Opaleye, FI (1990). Antibiotic Resistance among Coliform Bacteria Isolated from Hospital and Urban Wastewater. World Journal of Microbiology and Biotechnology, vol. 6 , pp $285-288$.

World Bank, (1993). Water Resources Management. World Bank Policy Paper. Washington, DC.

\footnotetext{
${ }^{*}$ Corresponding author: Joel, O. F.
} 